\title{
Effect of Whey Protein Concentrates (WPC) on Microbial and Textural Evaluation of Foxtail and Finger Millet Papad
}

\author{
D.B. Satpute*, G. K. Londhe and U.A. Chadar \\ Department of Animal Husbandry and Dairy Science, College of Agriculture, \\ Vasantrao Naik Marathwada Krishi Vidyapeeth, Parbhani- 431402 (Maharashtra), India \\ *Corresponding author
}

\section{A B S T R A C T}

\section{Keywords \\ WPC, Foxtail and finger millet, \\ Papad, Microbial and textural properties}

\section{Article Info}

Accepted:

20 October 2020

Available Online:

10 November 2020
Whey Proteins Concentrate (WPC) is an excellent source of dietary nitrogen and branched chain amino acids. Protein Concentrate (WPC) at different levels of substitution i.e. control $\left(\mathrm{T}_{0}\right), 2.5$ parts $\left(\mathrm{T}_{1}\right), 5$ parts $\left(\mathrm{T}_{2}\right)$, 7.5 parts $\left(\mathrm{T}_{3}\right)$ and 10 parts $\left(\mathrm{T}_{4}\right)$. In related to the microbial evaluation of raw foxtail and finger millet papad prepared from treatments $T_{0}$ to $T_{4}$ content, The total plate count, yeast and mold count of all samples of raw foxtail and finger millet papad was under acceptable limits. Textural analysis revealed that 10 parts of WPC supplemented foxtail and finger millet fried papad showed maximum Hardness (1.84 N) and Fracturability (0.96 mm).

\section{Introduction}

Papad is a popular and tasty food item in the Indian diet in many centuries, which is regularly consumed as a meal, accompaniment, after roasting or frying or as adjunct along with vegetable soups and curries (Chowdhury et al., 2009). It is also known as Appalam and essentially a thin wafer like product, circular in shape, rolled and nutritious as well.

Millets are important crops of Asia and Africa (especially in India and Nigeria), with 97 percent of millet production in developing countries. Various traditional foods and beverages such as roti, bread (fermented or unfermented), porridge, snacks and fast foods, baby foods, millet wine, millet nutrition powder etc. are made up of millets (Chandrasekara and Shahidi, 2012) and it contains $60-70$ per cent carbohydrates, 7-11 per cent proteins, $1.5-5$ per cent fat, and 2-7 per cent crude fibre and are also rich in vitamins and minerals. They are excellent source of vitamin B, magnesium, and antioxidants (Singh et al., 2012). Millets are also rich sources of micronutrients and phytochemicals (Liu, 2007). It is an alkaline forming food, alkaline based diet is often 
recommended to achieve optimal health, meaning when it combines with digestive enzymes. The soothing alkaline nature of millet helps to maintain a healthy $\mathrm{pH}$ balance in the body, crucial to prevent illnesses.

Foxtail millet (Setaria italica), a member of the family Poaceae, is one of the oldest cereal crops. Foxtail millet grain is rich in protein $(12.3 \%)$ and iron $(2.8 \mathrm{mg} / 100 \mathrm{~g})$ as compared to rice $(6.8 \%$ protein and $1.8 \mathrm{mg}$ iron $/ 100 \mathrm{~g}$ grain) and rich in fat 4.3 per cent which is superior to rice and wheat. The grain is good source of beta - carotene, which is the precursor of Vitamin A (Murugan and Nirmalakumari 2006). Foxtail millet is mixed with legumes to make porridge and also mixed with soybean to make mixed flour. Foxtail millet has low glycemic index (GI), used for preparation of low GI biscuits and burfi, a sweet product and it is an ideal for people suffering from diabetes (Anju and Sarita, 2010) and also fermented to make vinegar, yellow wine, maltose, beer and other related products.

Whey proteins are an excellent source of dietary nitrogen and branched chain amino acids which are used to fuel working muscles and stimulate protein synthesis. Whey protein has antimicrobial, antiviral and antioxidant properties, and they also act as technofunctional ingredients in many formulated food systems due to their good solubility, surface activity and gelling properties. In addition, whey proteins and their associated peptides display significant functional food ingredient potential (Chatterjee and Kanawjia, 2010).

\section{Materials and Methods}

\section{Millet grains}

Minor millets such as foxtail millet (DHF-1) and finger millet (CO-9) are procured from the Indian Institute of Millet Research (IIMR), Rajendranagar, Hyderabad.

\section{Whey Protein Concentrate (WPC)}

Whey Protein Concentrate (WPC-70) required for study was purchased from Modern dairy limited, Karnal.

\section{Ingredients}

Salt, alkaline salt (papad khar), red chilly powder, cumin, sesamum, asafoetida and fortune soybean oil was procured from the local market of Parbhani (Table 1 and 2).

\section{Chemicals and glassware's}

Chemicals (Analytical grade) were procured from standard firms and glassware's required for conducting chemicals analysis and preparation of product utilized from laboratory of department of AHDS, VNMKV, Parbhani.

\section{Treatment details}

During this papad preparation two minor millets viz. Foxtail millet (DHF-1) and Finger millet (CO-9) were utilized with WPC.

$\mathrm{T}_{0}-70$ parts Foxtail millets +30 parts finger millet

$\mathrm{T}_{1}-67.5$ parts of Foxtail millets +30 parts finger millet +2.5 parts of WPC

$\mathrm{T}_{2}-65.0$ parts of Foxtail millets +30 parts finger millet +5.0 parts of WPC

$\mathrm{T}_{3}-62.5$ parts of Foxtail millets +30 parts finger millet +7.5 parts of WPC

$\mathrm{T}_{4}-60.0$ parts of Foxtail millets +30 parts finger millet +10.0 parts of WPC 
Flow diagram for preparation of protein enriched foxtail and finger millet Papad

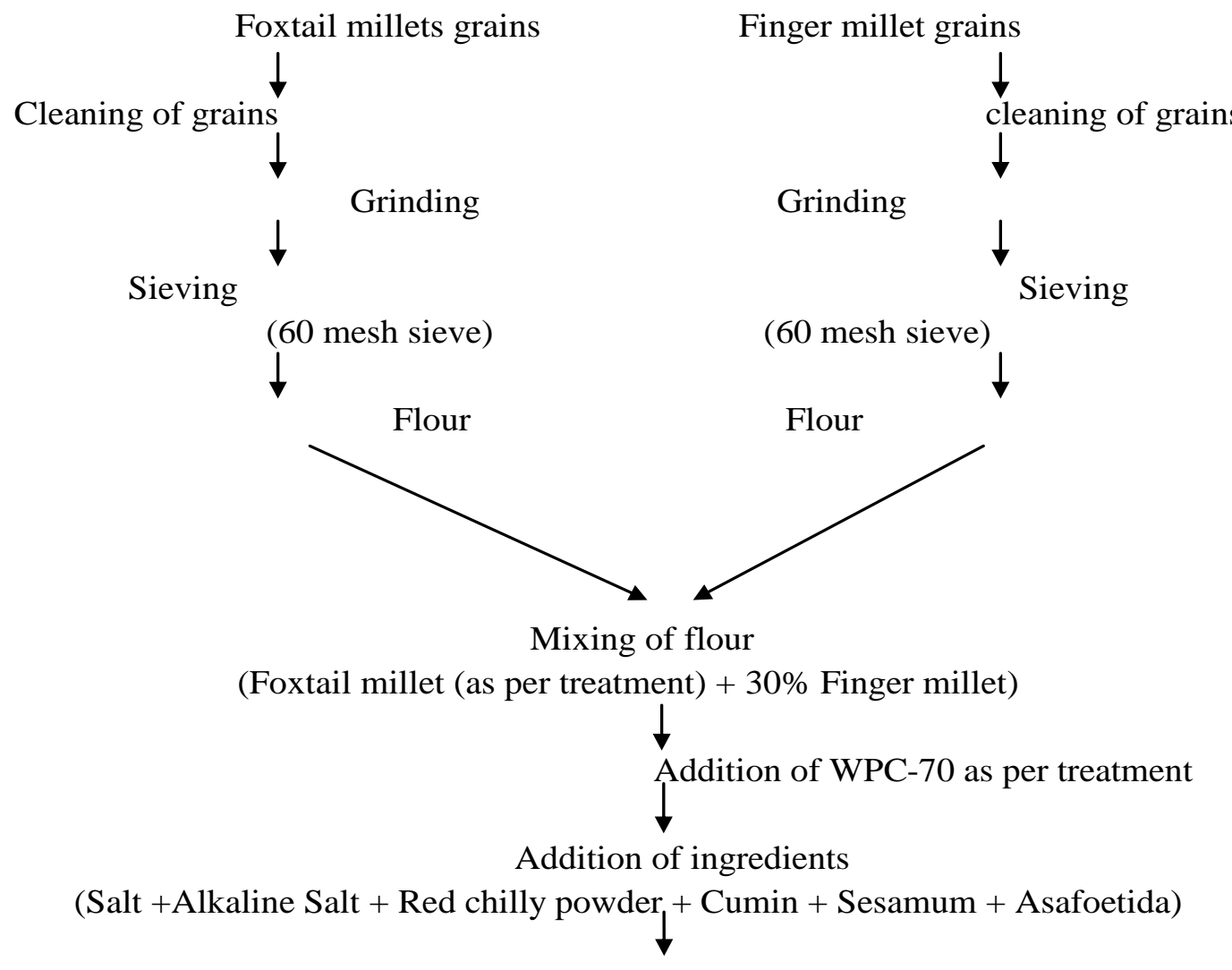

Add above mixture in boiling water and Stirring well

(Flour: water -1:2)

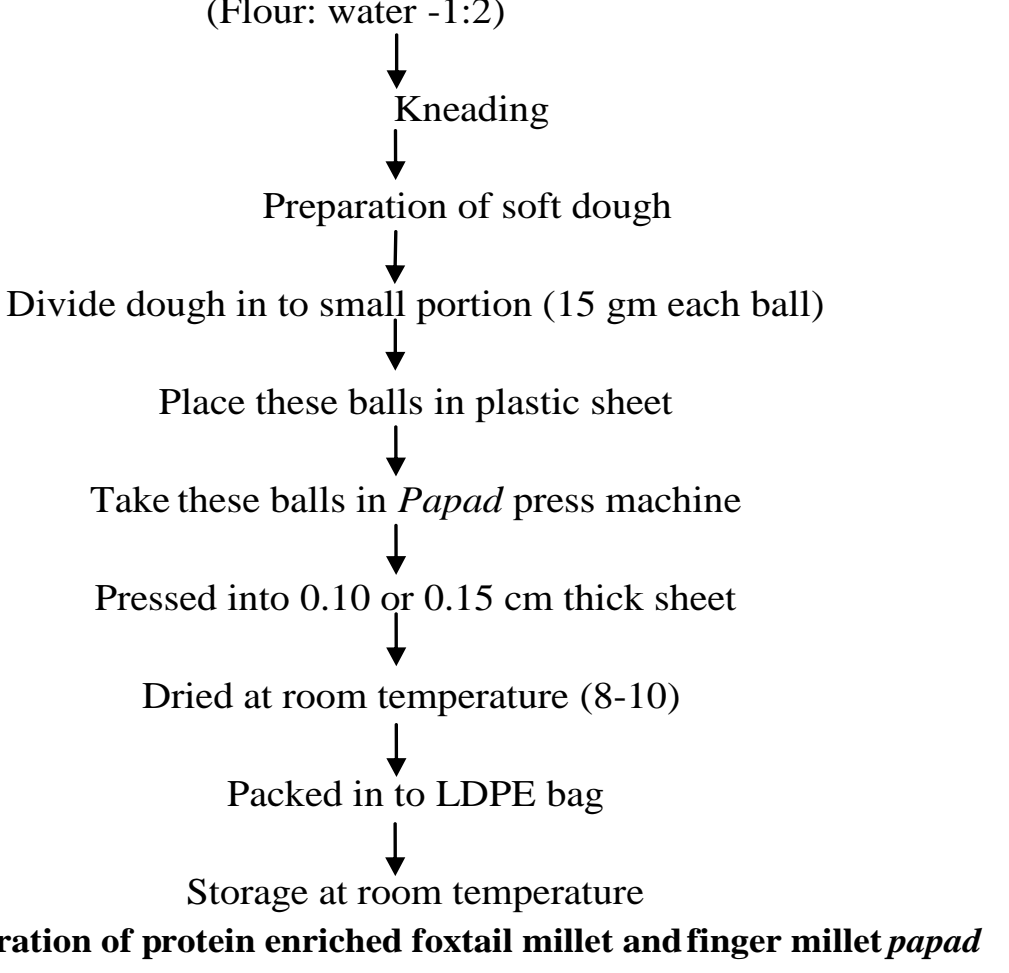




\section{Methodology}

\section{Microbiology of Papad}

All samples were analyzed for different microbial counts such as total plate count and yeast and mold count by adopting standard procedures.

\section{Total plate count}

The total plate count of protein enriched foxtail and finger millet papad was determined by using total plate count method using Nutrient Agar. The dilution where made up to $10^{-6}$ and the $1 \mathrm{ml}$ of aliquot was used for the isolation. All processes were carried out in a sterile area with the help of laminar air flow. Plate was incubated at $37^{\circ} \mathrm{C}$ for 48 hr. and results noted in CFU/ml. Total plate count (TPC) of papad were examined at 1 to 6 months (Chandru et al., 2010).

\section{Yeast and mould count}

Yeast and mould count was determined by the method cited in ISI (IS: 5403) 1969 using potato glucose agar up to 1 to 6 months.

\section{Textural characteristics of Papad}

Stable Micro System TAXT2 plus Texture Analyzer was used for texture profile analysis (TPA) of protein enriched minor millet papad prepared by lab sample. A spherical-end probe of $6.35 \mathrm{~mm}$ of diameter with test speed of $1 \mathrm{~mm} / \mathrm{sec}$. of pre-test and post-test speeds; and $50 \%$ compression was taken for TPA analysis. TPA is "two-bite" test, which includes the first and second compression cycles. The first and second compression cycles indicate the force vs. time data during the first and second compression of the product by the instrument probe. There were two replications of the instrumental analysis conducted on two separate days. For each replication, minor millet papad incorporated with different proportions of WPC were evaluated.

\section{Statistical analysis}

The data obtained was analysed using Completely Randomize Design ( Panse and Sukhatme, 1985 ).

\section{Results and Discussion}

\section{Effect of WPC on microbial qualities of finger millet raw Papad}

It is revealed from table 3 that after 30 days of storage total plate count was found in $\mathrm{T}_{3}$ and $\mathrm{T}_{4}$ and not detected in rest of treatments. After 60 days of storage the TPC was increased from $\mathrm{T}_{2}\left(0.58 \times 10^{2} \mathrm{CFU} / \mathrm{g}\right)$. From Table 3, it can be concluded that after 90 days of storage the samples of foxtail and finger millet papad with 10 pars of WPC supplemented $\left(\mathrm{T}_{4}\right)$ tend to have higher mean Total plate counts than those with $T_{3}, T_{2}, T_{1}$ and $T_{0}$. The maximum Total plate count on nutrient agar was observed in $\mathrm{T}_{4}$ (10 parts WPC supplemented papad) and minimum in $\mathrm{T}_{0}$ (control) for 90 , 120,150 and 180 days of storage period. Results revealed that the total plate count of all samples does not differ significantly. The increase in microbial load of WPC supplemented foxtail and finger millet papad as compared to control may be due to increase in moisture content with increasing WPC supplementation level. The growths of TPC were in increasing order as storage period increased. As per the WHO (1994) guidelines the total plate count should be less than $2 \mathrm{x}$ $10^{5}$ per gram. The result of this study in respect of TPC was in acceptable limit.

From table 4, it was observed that the yeast and mould growth was not detectable up to 30 days of storage in all treatments and after 60 days of storage yeast and mould count was 
observed only in treatment $\mathrm{T}_{4}\left(0.65 \times 10^{2}\right.$ $\mathrm{CFU} / \mathrm{g})$. After 90 days of storage yeast and mould count was observed in $T_{2}, T_{3}$ and $T_{4}$ and absent in $T_{0}$ and $T_{1}$. After 120 days of storage the samples of foxtail and finger millet papad with 10 parts of WPC supplemented $\left(\mathrm{T}_{4}\right)$ tend to have higher mean yeast and mould counts than those with $\mathrm{T}_{3}$, $\mathrm{T}_{2}, \mathrm{~T}_{1}$ and $\mathrm{T}_{0}$. The maximum yeast and mould count was observed in $\mathrm{T}_{4}$ (10 pars WPC supplemented papad) and minimum in $\mathrm{T}_{0}$ (control) for 120, 150 and 180 days of storage. Results of this study revealed that the yeast and mould count of all samples does not differ significantly. The increase in yeast and mould count of WPC supplemented millet papad as compared to control may be due to increase in moisture content with increasing WPC supplementation level. As per the WHO (1994) guideline the Yeast and mold count should be less than $1 \times 10^{4}$ per gram. Above results related to yeast and mould count was within the acceptable limit.

Maximum hardness was observed for foxtail and finger millet fried papad prepared using
10 parts of WPC $(1.84 \mathrm{~N})$ and minimum $(1.61 \mathrm{~N})$ for foxtail and finger millet fried papad prepared by without addition of WPC. Hardness of foxtail and finger millet fried papad in peak positive force was increases as the incorporation of WPC increases from 0 to 10 parts. Variation in hardness of protein enriched foxtail and finger millet fried papad samples might be due to protein content; it hold recipe water and binds other ingredients and increases the breaking strength or hardness of the product. Present results are in agreement with Wani et al., (2015) indicated that, the highest peak force was observed in 6 (\%) WPC supplemented cookies $(55.3 \mathrm{~N})$, followed by control cookies $(50.2 \mathrm{~N})$. Fracturability of foxtail and finger millet fried papad was ranged from 0.76 to $0.96 \mathrm{~mm}$. Fracturability of fried papad increased as the incorporation of WPC increases from 0 to 10 parts. It is may be due to the increasing hardness of developed product. The fracturability of the foxtail and finger millet fried papad with 10 parts WPC $\left(\mathrm{T}_{4}\right)$ was significantly $(\mathrm{P}<0.05) \quad$ superior over all treatments.

Table.1 Recipe for preparation of protein enriched minor millet Papad

\begin{tabular}{|c|c|c|}
\hline Sr. No & Ingredients & Quantity for $\mathbf{1 0 0}$ gm \\
\hline $\mathbf{1}$ & & $2 \mathrm{gm}$ \\
\hline $\mathbf{2}$ & Salt & $3 \mathrm{gm}$ \\
\hline $\mathbf{3}$ & Alkaline Salt (Papadkhar) & $1 \mathrm{gm}$ \\
\hline $\mathbf{4}$ & Red chilly powder & $1.5 \mathrm{gm}$ \\
\hline $\mathbf{5}$ & Cumin & $2 \mathrm{gm}$ \\
\hline $\mathbf{6}$ & Sesamum & $0.5 \mathrm{gm}$ \\
\hline $\mathbf{7}$ & Asafoetida & $200-220 \mathrm{ml}$ \\
\hline $\mathbf{8}$ & Water & As per treatment combinations \\
\hline
\end{tabular}


Table.2 Chemical composition of WPC, foxtail and finger millet grains

\begin{tabular}{|c|c|c|c|c|}
\hline $\begin{array}{c}\text { Sr. } \\
\text { no }\end{array}$ & Composition & WPC Powder & $\begin{array}{c}\text { Foxtail millet } \\
\text { Grains }\end{array}$ & $\begin{array}{c}\text { Finger millet } \\
\text { Grains }\end{array}$ \\
\hline $\mathbf{1}$ & Total Solid (\%) & 96.96 & 91.95 & 90.10 \\
\hline $\mathbf{2}$ & Ash (\%) & 6.20 & 1.09 & 2.40 \\
\hline $\mathbf{3}$ & Moisture (\%) & 3.04 & 9.42 & 9.50 \\
\hline $\mathbf{4}$ & Protein (\%) & 70.85 & 13.0 & 8.80 \\
\hline $\mathbf{5}$ & Fat (\%) & 6.50 & 3.67 & 3.90 \\
\hline $\mathbf{6}$ & Carbohydrate (\%) & - & 74.19 & 75.00 \\
\hline $\mathbf{7}$ & NPN (\%) & 0.18 & - & - \\
\hline $\mathbf{8}$ & Calcium (\%) & 1.70 & - & - \\
\hline $\mathbf{9}$ & Chloride (\%) & 1.57 & - & - \\
\hline $\mathbf{1 0}$ & Acidity (\%) & 1.62 & - & - \\
\hline
\end{tabular}

(Rathour et al., 2016; Nazni and Bhuvaneshwari, 2015; Kamtkar et al., 2015)

Table.3 Effect of WPC on total plate count $\left(\times 10^{2} \mathrm{CFU} / \mathrm{g}\right)$ of foxtail and finger millet raw papad

\begin{tabular}{|c|c|c|c|c|c|c|c|}
\hline & \multicolumn{7}{|c|}{ Storage period in days $(\times \mathbf{1 0} \mathbf{C F U} / \mathbf{g})$} \\
\cline { 2 - 8 } Treatment & $\mathbf{0 0}$ & $\mathbf{3 0}$ & $\mathbf{6 0}$ & $\mathbf{9 0}$ & $\mathbf{1 2 0}$ & $\mathbf{1 5 0}$ & $\mathbf{1 8 0}$ \\
\hline $\mathbf{T}_{\mathbf{0}}$ & ND & ND & ND & 0.45 & 1.00 & 1.75 & 2.50 \\
\hline $\mathbf{T}_{\mathbf{1}}$ & ND & ND & ND & 0.64 & 1.20 & 2.75 & 3.75 \\
\hline $\mathbf{T}_{\mathbf{2}}$ & ND & ND & 0.58 & 0.90 & 1.75 & 3.20 & 4.65 \\
\hline $\mathbf{T}_{\mathbf{3}}$ & ND & 0.65 & 0.82 & 1.50 & 2.50 & 4.50 & 5.75 \\
\hline $\mathbf{T}_{\mathbf{4}}$ & ND & 0.85 & 1.20 & 2.50 & 3.75 & 5.50 & 6.75 \\
\hline SE & $\mathbf{0 . 0 0}$ & $\mathbf{0 . 0 9}$ & $\mathbf{0 . 0 5}$ & $\mathbf{0 . 0 4}$ & $\mathbf{0 . 0 5}$ & $\mathbf{0 . 0 5}$ & $\mathbf{0 . 0 3}$ \\
\hline $\mathbf{C D}$ at 5\% & $\mathbf{0 . 0 0}$ & $\mathbf{0 . 2 7}$ & $\mathbf{0 . 1 5}$ & $\mathbf{0 . 1 2}$ & $\mathbf{0 . 1 5}$ & $\mathbf{0 . 1 5}$ & $\mathbf{0 . 0 9}$ \\
\hline
\end{tabular}

Table.4 Effect of WPC on yeast and mould count $\left(\times 10^{2} \mathrm{CFU} / \mathrm{g}\right)$ of raw foxtail and finger millet papad

\begin{tabular}{|c|c|c|c|c|c|c|c|}
\hline \multirow{2}{*}{ Treatment } & \multicolumn{7}{|c|}{ Storage period in days $\left(\times \mathbf{1 0}^{\mathbf{2}} \mathbf{C F U} / \mathbf{g}\right)$} \\
\cline { 2 - 8 } & $\mathbf{0 0}$ & $\mathbf{3 0}$ & $\mathbf{6 0}$ & $\mathbf{9 0}$ & $\mathbf{1 2 0}$ & $\mathbf{1 5 0}$ & $\mathbf{1 8 0}$ \\
\hline $\mathbf{T}_{\mathbf{0}}$ & ND & ND & ND & ND & 0.25 & 0.75 & 1.25 \\
\hline $\mathbf{T}_{\mathbf{1}}$ & ND & ND & ND & ND & 0.45 & 1.20 & 1.75 \\
\hline $\mathbf{T}_{\mathbf{2}}$ & ND & ND & ND & 0.25 & 0.75 & 1.75 & 2.50 \\
\hline $\mathbf{T}_{\mathbf{3}}$ & ND & ND & ND & 0.75 & 1.25 & 2.50 & 3.15 \\
\hline $\mathbf{T}_{\mathbf{4}}$ & ND & ND & 0.65 & 1.25 & 2.00 & 2.75 & 3.95 \\
\hline $\mathbf{S E}$ & $\mathbf{0 . 0 0}$ & $\mathbf{0 . 0 0}$ & $\mathbf{0 . 0 1}$ & $\mathbf{0 . 0 3}$ & $\mathbf{0 . 0 3}$ & $\mathbf{0 . 0 7}$ & $\mathbf{0 . 0 6}$ \\
\hline $\mathbf{C D} \mathbf{a t} \mathbf{5 \%}$ & $\mathbf{0 . 0 0}$ & $\mathbf{0 . 0 0}$ & $\mathbf{0 . 0 3}$ & $\mathbf{0 . 0 9}$ & $\mathbf{0 . 1 0}$ & $\mathbf{0 . 2 1}$ & $\mathbf{0 . 1 8}$ \\
\hline
\end{tabular}


Table.5 Effect of WPC on textural properties of foxtail and finger millet fried Papad

\begin{tabular}{|c|c|c|}
\hline Treatments & Hardness $(\mathbf{N})$ & Fracturability $(\mathbf{m m})$ \\
\hline $\mathbf{T}_{\mathbf{0}}$ & $1.61^{\mathrm{a}}$ & $0.76^{\mathrm{a}}$ \\
\hline $\mathbf{T}_{\mathbf{1}}$ & $1.67^{\mathrm{b}}$ & $0.82^{\mathrm{b}}$ \\
\hline $\mathbf{T}_{\mathbf{2}}$ & $1.72^{\mathrm{c}}$ & $0.87^{\mathrm{c}}$ \\
\hline $\mathbf{T}_{\mathbf{3}}$ & $1.77^{\mathrm{d}}$ & $0.92^{\mathrm{d}}$ \\
\hline $\mathbf{T}_{\mathbf{4}}$ & $1.84^{\mathrm{e}}$ & $0.96^{\mathrm{e}}$ \\
\hline $\mathbf{S E}$ & $\mathbf{0 . 0 1}$ & $\mathbf{0 . 0 1}$ \\
\hline CD at 5\% & $\mathbf{0 . 0 3}$ & $\mathbf{0 . 0 3}$ \\
\hline
\end{tabular}

Hence concluded, in view of experimental results obtained during the present investigation, as supplementation of WPC increases microbial quality such as TPC and yeast and mold increased in foxtail and finger millet papad. The TPC and Yeast and mold count in all samples for period of six months was found within acceptable limits. WPC supplementation affected textural characteristic of fried Papad, the hardness and fracturability increases with increase in the WPC level.

\section{References}

Anju, T and Sarita, S. 2010. Suitability of Foxtail Millet (Setaria ITALICA) and Barnyard Millet (Echinochloa frumentacea) for Development of Low Glycemic Index Biscuits. Malays Journal of Nutrition, 16(3): 361-368.

Chandrasekara, A. and Shahidi, F. 2012. Bioaccessibility and Antioxidant Potential of Millet Grain Phenolics as Affected by Simulated in Vitro Digestion and Microbial Fermentation. Journal of Functional Foods, 4: 226237.

Chatterjee, A. and Kanawjia, S. K. 2010. Whey Proteins for Healthy Living. Indian Dairyman, 66-73.

Chowdhury, M.G.F., Miaruddin, M., Rahman, M. M., Islam M.S. and Tariqul Islam A.F. 2009. Study on the Effect of Preservative on the Storage Quality of
Spiced Papads. Journal of Innovation and Development Strategy, 3(1): 30-33.

Garg, R. and Dahiya, S. 2003. Nutritional Evaluation and Shelf Life Studies of Papads Prepared from Wheat Legume Composite Flours. Plants Foods for Human Nutrition, 58 (4): 299-307.

Haupt, M. F., Mckee, D. M., Mayers, G. and Pollina, L. K. 1997. Fortification of Corn bread with Lysine. Journal of American Dietetic Association. 97: A83-A88.

Kamatar, M. Y., Brunda, S. M., Rajaput, S, Sowmya, H. H. and Goaudhar, G. 2015. Nutritional Composition of Seventy Five Elite Germplasm of Foxtail Millet (Setaria italica). International Journal of Engineering and Technical Research, 4(4):1-6.

Liu, R.H. 2007. Whole Grain Phytochemicals and Health. Journal of Cereal Science, 46(3): 207-219.

Murugan R and Nirmalkumari A .2006. Genetic Divergence in Foxtail Millet (Setaria italica (L.) Beauv). Indian Journal of Genetics. 66(4): 339-340.

Nazni and Bhuvaneshwari. 2015. Analysis of Physico Chemical and Functional Characteristics of Finger Millet (Eleusine corcana L) and Little Millet (Panicum sumantarnce). International Journal of Food and Nutritional Sciences, 4(3): 109-114.

Panse, Y. P. and Sukatme, P. V. 1961. Statistical Methods for Agricultural 
Workers, $2^{\text {nd }}$ edn. Indian Council of Agricultural Research, New Delhi.

Rathour, A. K., Rathore, V., Mehta, B. M., Patel, S. M., Chauhan, A. and Aparnathi, K. D. 2016. Standardization and Storage Study of Whey Protein Concentrate (WPC-70) Prepared From Buffalo Milk Using Ultrafiltration Membrane Technology. Journal of Food Processing and Preservation. 41: 1-8.

Singh, K. P., Mishra, A, Mishra, H. N 2012. Fuzzy Analysis of Sensory Attributes of Bread Prepared from Millet-Based Composite Flours. LWT-Food Science and Technology, 48(2): 276-82.

Vedprakash, D. and Madhavareddy, R. 2018.
Studies on Traditional Indian Fermented food: Characterization and Development of Jowar papad. Int. J. Curr. Microbiol. App. Sci. 6: 866-882. Wani, S. H., Gull, A., Allaie, F. and Safapuri, T. A. 2015. Effects of Incorporation of Whey Protein Concentrate on Physicochemical, Texture, and Microbial Evaluation of Developed Cookies. Cogent Food and Agriculture: $1-9$.

WHO (World Health Organization) 2011. Vitamin A supplementation in infants and children 6 to 9 months of age. www.worldfoodprize.org.

\section{How to cite this article:}

Satpute, D.B., G. K. Londhe and Chadar, U.A. 2020. Effect of Whey Protein Concentrates (WPC) on Microbial and Textural Evaluation of Foxtail and Finger Millet Papad. Int.J.Curr.Microbiol.App.Sci. 9(11): 2554-2561. doi: https://doi.org/10.20546/ijcmas.2020.911.309 